\title{
Ortaöğretim Öğrencilerinde Görülen Madde Bağımlılığı Alışkanlığı ve Yaygınlığı: Bartın İli Örneği
}

DOI NO: $10.5578 / J S S .7521$

\author{
Gürcï Erdamar ${ }^{1}$ \\ Abdülhamit Kurupınar ${ }^{2}$
}

\section{Özet}

Bu araştırmanın amacı, ortaöğretim ögrencilerinde görülen madde

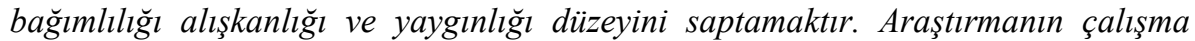
grubunu, Bartın ilindeki ortaögretim kurumlarında ögrenim gören her sinıf seviyesindeki ögrencilerden tesadüfi seçilen toplam 545 ögrenci oluşturmuştur. Veri toplama aracı olarak, araştırmacılar tarafindan geliştirilen bir anket kullanılmıştır. Araştırmada elde edilen bulgulara göre, Bartın ilindeki ortaögretim öğrencilerinin $\% 61.8$ 'sinin ( $n=337$ ) şimdiye kadar hiç sigara kullanmadı $\breve{l}, \% 10.8$ 'inin $(n=59)$ bir kez denediği, buna karşın \% 27.4'ünün $(n=149)$ sigara kullanmaya devam ettiğ $i$ tespit edilmiştir. Aynı zamanda grubun \% 35.2 'sinin $(n=192)$ en az bir kez alkol kullandiğ ve bunların da \% 24.4'ünün $(n=131)$ halen belli aralıklarla alkol kullanmaya devam ettiği belirlenmiştir. Ayrica sigara ve alkol kullanma ile cinsiyet, sınıf düzeyi ve madde bă̆ımlısı arkadaşı olması arasında; sigara kullanma ile okul türü ve kendinden memnun olma arasında anlamlı fark bulunmuştur.

Anahtar Kelimeler: Ergen, Madde bă̆ımlılı̆̆l, Alışkanlık

\section{The Habit of Drug Addiction and Prevalence Among the Secondary School Students: Sample of Bartın City}

\begin{abstract}
The aim of this study was to determine the prevalence level of drug addiction habit seen in the secondary school students. The study group was a total of 545 students attending in secondary schools in Bartin who were randomly
\end{abstract}

${ }^{1}$ Doç. Dr., Gazi Üniversitesi, Gazi Eğitim Fakültesi. gurkoc@gazi.edu.tr

${ }^{2}$ Rehber Öğretmen, Bartın Anadolu İmam Hatip Lisesi. abdulhamit@gmail.com 
selected from each grade level. A questionnaire developed by the researchers was used as data collection tool. According to the results obtained in this study, it was identified that $61.8 \%(n=337)$ of the secondary school students in Bartin never smoked, $10.8 \%$ of the students $(n=59)$ tried smoking only once; whereas $27.4 \%$ of the students $(n=149)$ were continuous smokers. Also, it was determined that $35.2 \%$ of the students $(n=192)$ used alcohol at least once, and $24.4 \%$ of them $(n=131)$ still continued to use alcohol at regular intervals. Additionally, a statistically significant difference was found between smoking and alcohol use and gender; grade level and having friends who are addicted to drugs; smoking and the school type and being self-satisfied.

\section{Keywords: Adolescent, Drug addiction, Habit}

\section{Giriş}

İnsan, çevresinde bulunan bütün canlilara ve nesnelere birbirinden farklı ilgi ve sevgi duyar. Bu nedenle onlara farklı biçimde bağlanabilir. Ancak bu bağlılık tutku ve tutsaklık durumuna gelince bağımlılık oluşur. Bağımlılık türlerinden birisi olan madde bağımlılığı çocukların ve gençlerin önündeki en önemli tehlikelerden birisidir. Bektaş, madde bağımlılığını "bağımlılık yapıcı maddenin uzun süre ya da kısa ve düzenli kullanılması durumunda bedenin bağımlılık yapıcı maddenin etkisine alışması, alışılan maddenin alınmaması ya da azaltılması durumunda ise, bedende yorgunluk belirtilerinin ortaya çıkması", Ögel ise "kişinin kullandığı maddeyi birçok kez bırakma girişiminde bulunmasına rağmen bırakamaması, giderek madde dozunu arttırması, kullanmayı bıraktığında yoksunluk belirtilerinin ortaya çıkması, zararlarını görmesine rağmen madde kullanmayı sürdürmesi, zamanının büyük bölümünü madde arayarak geçirmesi" olarak tanımlamaktadır (Bektaş, 1991; Ögel, 2001). Bağımlılık yapıcı maddeler arasında özellikle en fazla kullanılanlar sigara ve alkoldür. Diğer dikkat çeken maddeler ise uçucu (katı, sıvı veya gaz) ve uyuşturucu (esrar, eroin, ekstazi vb.) nitelikte olanlardır.

Son yıllarda çocuk ve gençler tarafından zararlı olduğu tespit edilen ve bağımlılık yaptığı bilinen maddeleri kullanan birey sayısı hızla artmaktadır. Ergenlik dönemi içerisinde yer alan gençlerin, ortaöğretim hayatlarında bağımlılık yapıcı maddeler ile tanışma riski diğer zamanlara oranla daha fazladır. Ülkemizde son yıllarda yapılan araştırmalarda ergenlik dönemindeki gençlerin madde kullanımında hızlı bir artış olduğu tespit edilmiştir (Gürol, 2008; Köknel, 2001; Meclis Araştırma Komisyonu Raporu, 2008).

$\mathrm{Bu}$ araştırmalardan bazılarına bakılacak olursa; 1995 yılında İstanbul'da yapılan bir araştırmada öğrencilerin \% 68.0'ının yaşamları boyunca en az bir kez tütün içtiği, \%56.2' sinin yaşamları boyunca en az bir 
kez alkollü içecek aldığı, son bir ay içinde ise \%23.5'inin alkol kullandığ1 saptanmıştır. Öğrenciler arasında esrar kullanımı \% 4, uçucu madde kullanımı ise \% 3.8 bulunmuştur (Yazman, 1995).

2003 yılında lise ikinci sınıf öğrencileri üzerinde yapılmış olan bir yaygınlık çalışmasında yaşam boyu herhangi bir madde kullanımı $\% 6$, esrar kullanımı \% 5.1, uçucu madde kullanımı \% 5.2, ekstazi kullanımı \%3.2, eroin kullanımı \% 2.8 bulunmuştur. Gençler arasında madde kullanım yaygınlığının artma hızı ise çok daha çarpıcı veriler sunmaktadır. 2001-2004 yılları arası esrar kullanımı \% 75.7, uçucu madde kullanımı \% 40.5, ekztazi kullanımı \% 287.5 ve eroin kullanımı \% 100 artmıştır (Gürol, 2008). Özellikle sigara ve alkol kullanımı büyük oranda birlikte görülmekte, bunları diğer bağımlılık yapıcı maddeler izlemektedir.

2008 yılında Meclis Araştırma Komisyonunun yaptırdığ 1 bir araştırmada ise, ortaöğretim kurumlarına devam eden gençlerin sigara kullanma yüzdeleri 15.6 (erkeklerde \% 21.8 ve kızlarda \% 7.5), son bir ayda en az bir defa alkollü içki içme yüzdesi 16.5 (erkeklerde \%31.5 ve kızlarda \%10.6) ve son üç ay içinde uyuşturucu/uyarıcı madde kullanma yüzdesi 2.9 (erkeklerde \% 4.3 ve kızlarda \% 1.0) olarak bulunmuştur.

Ülkemizde son yıllarda genç nüfus üzerinde yapılan araştırmaların verileri kıyaslandığında, tütün ve alkol dışındaki tüm maddelerin kullanım yaygınlığında bir artış görülmüştür. Mutlak değişim değerlerinde en yüksek artış1 gösteren maddeler sırasıyla; esrar, ekstazi, uçucular ve eroindir (Ögel vd., 2004; Ögel, 2006).

Sonuç olarak, madde bağımlılığ toplumu tehdit eden en önemli halk sağlığı sorunlarından biridir. Madde bağımlılığı açısından ergenler en önemli risk grubunda yer almaktadır (Gürol, 2008). Ayrıca genç bir nüfusa sahip olan ülkemizde ergenler toplumun önemli bir bölümünü oluşturmaktadır. Meclis Araştırma Komisyonunun 2008 yılında yaptırdığ 1 araştırma sonucuna göre, madde kullananların yaklaşık \% 75.0'i, madde kullanmaya 20 yaşından önce başlamaktadır (Meclis Araştırma Komisyonu Raporu, 2008).

Ergenlik döneminde gençler, çevrelerindeki arkadaşlarından ya da kendileri ile özdeşleştirdikleri kişilerden etkilenmeye açıktırlar. $\mathrm{Bu}$ etkileşim içindeki gençler sigara, alkollü içki ve uyuşturucu madde kullanmayı deneyebilir ve hatta bunları alışkanlık haline getirebilirler (Yörükoğlu, 1996). Madde kullanımı, genellikle ergenlik döneminde başlamakta ve psikolojik, sosyal ve kültürel etkiler önemli rol oynamaktadır. Erken yaşlarda madde kullanımının önlenmesi, daha sonraki dönemde de kullanımının azalmasını sağlamaktadır (Gürol, 2008; Herken, Bodur ve Kara, 2000). Literatürde okullarda uygulanan sigara karşıtı eğitim programlarının sigarayı önlemede etkili olduğuna ilişkin araştırma sonuçları bulunmaktadır (Doğan ve Ulukol, 2010; Paavola, Vartianien ve Puska, 2001). Bu nedenlerle ortaöğretim ve hatta ilköğretim öğrencilerinde madde 
bağımlılığ 1 alışkanlığ 1 ile ilgili çalışmaların aralıklarla tekrarlanmasında ve önleme çalışmalarına başlanmasında yarar vardır.

Ergenlerde madde bağımlılığını etkileyen pek çok risk faktörü bulunmaktadır. Madde bağımlılı̆̆ı ile ilişkisi en fazla araştırılan değişkenler yaş, cinsiyet, kişilik özellikleri, anne-babanın eğitim düzeyi, aileden ya da arkadaşlardan birisinin sigara kullanma durumu gibi faktörlerdir (Steinberg, 2007, Tekalan, 2012). Bu faktörlerden özellikle arkadaş etkisi ön plana çıkmaktadır. Madde bağımlısı arkadaşı bulunan ergenler, madde bağımlısı arkadaşı olmayanlara göre daha fazla madde kullanmaya yönelmektedir (Erdem vd., 2006; Springer, Sale ve Hermann, 2004; Steinberg, 2007). Ayrıca erkek öğrencilerin kız öğrencilere göre (Gökgöz ve Koçoğlu, 2007; Turhan vd., 2011; Web vd., 1998) lise öğrencilerinin ortaokul öğrencilerine göre (Smith, 2004) daha fazla madde kullandığı saptanmıştır. Bu çevresel faktörlerin yanında alkol kullanımının genetik faktörlerden kaynaklanabileceği de belirtilmektedir (Prescoot, Aggen ve Kendler, 2000; Rezvanfard, Ekhtiari ve Mokri, 2009). Anne ve babas1 alkol bağımlısı olan erkek çocukların alkol bağımlısı olma riski, anne-babası alkol bağımlısı olmayanlara göre 4-5 kat daha yüksektir (Alikaşifoğlu ve Ercan, 2002). Zincir ve arkadaşları (2012), sigara ve alkol kullanımı ve bağımlılığın depresyon, anksiyete, iki uçlu bozukluk, antisosyal kişilik bozukluğu, şizofreni, sınır kişilik özellikleri gibi bir çok psikiyatrik durumla ilişkili olduğunu vurgulamaktadır.

$\mathrm{Bu}$ çalışmada ortaöğretim öğrencilerinde madde bağımlılığ alışkanlığını ve yaygınlığını tespit etmek amaçlanmıştır. Bu genel amaca ulaşmak için aşağıdaki alt amaçlara cevap aranmıştır:

1. Ortaöğretim öğrencilerinde görülen madde bağımlılığı alışkanlığı ve yaygınlı̆̆ 1 ne düzeydedir?

2. Ortaöğretim öğrencilerinin madde bağımlılı̆̆ alışkanlığı ile öğrencilerin cinsiyeti, sınıf düzeyi, devam ettiği okul türü, arkadaş gruplarında madde bağımlısı olup olmadığı ve öğrencinin kendinden memnuniyet düzeyi arasında anlamlı bir fark var mıdır?

\section{Yöntem}

\subsection{Araştırma Modeli}

Ortaöğretim öğrencilerinin madde bağımlılığı alışkanlığı ve yaygınlık düzeyini belirlemek için gerçekleştirilen bu araştırmada, betimsel yöntem kullanılmıştır. Betimleme araştırmaları, mevcut olayların daha önceki olay ve koşullarla ilişkilerini de dikkate alarak durumlar arasındaki etkileşimi açıklamayı hedef almaktadır (Karasar, 2006). Bu nedenle çalışmada betimsel yöntem tercih edilmiştir. 


\subsection{Evren ve Örneklem}

Araştırmanın evrenini 2010-2011 öğretim yılında Bartın il merkezinde bulunan ortaöğretim kurumlarında öğrenim gören 4396 erkek ve 3892 kız öğrenci olmak üzere toplam 8288 öğrenci oluşturmaktadır. Evrenden örneklem alma yoluna gidilmiştir. Araştırmanın örneklemini belirlemek için, tabakalı örnekleme yönteminin oranlı seçimi kullanılmıştır. Tabakalı örnekleme yöntemi sosyal bilimlerdeki pek çok araştırma için, özellikle homojen olmayan evrenlerde, uygun bir örnekleme yoludur (Baykul, 1997). Öncelikle evren, okul türü bazında dört alt tabakaya ayrılmıştır. Bu tabakalar meslek lisesi, Anadolu lisesi, genel lise, fen lisesi ve öğretmen lisesidir. Ardından okul türlerinin evrendeki oranı hesaplanmış ve örneklem grubu oluşturulurken bu oranlar dikkate alınmıştır. Okulların belirlenmesinde küme örnekleme yöntemi kullanılmıştır. Buna göre bir Fen Lisesi, bir Anadolu Öğretmen Lisesi, bir Anadolu Lisesi, 2 Genel Lise, bir Anadolu İmam Hatip Lisesi, bir Endüstri Meslek Lisesi, bir Kız Meslek Lisesi ve bir Ticaret Meslek Lisesi olmak üzere toplam 9 lise örneklem grubunda yer almıştır. Okullardaki öğrenci sayıları farklı olduğu için örnekleme alınacak birey sayısının okullara göre dağılımı belirlemek amacıyla oranlı örneklem yöntemi kullanılmıştır. Son olarak tesadüfî örnekleme yöntemi ile örnekleme alınacak kişiler seçilmiştir. Buna göre evrenden tesadüfî örneklem yöntemi ile seçilen dokuz ortaöğretim kurumundan 545 öğrenci araştırmanın örneklemini oluşturmaktadır. Öğrencilerin okul, sınıf ve cinsiyete göre dağılımları Tablo 1'de verilmiştir.

Tablo 1'de görüldüğü gibi öğrencilerin \%44.8'i (244) k1z, \%55.2'i (301) erkektir. Erkek ve kız öğrenci oranlarının birbirine yakın olduğu görülmektedir. Araştırmayı oluşturan öğrencilerin halen devam ettikleri okul türüne göre dağılımı incelendiğinde \%55.4'ünün (302) meslek lisesine, \%27.1'inin (148) genel liseye, \%11.3'ünün (62) Anadolu lisesine ve \%6.2'sinin (33) Fen lisesi+Anadolu öğretmen lisesine devam ettiği görülmektedir. Öğrencilerin \%22.8'i (124) 9. sınıf, \% 26.0'1 (141) 10. sınıf, \%25.5'i (140) 11. sınıf, \%25.7'si (140) 12. sınıf öğrencisidir. 
G. Erdamar vd. / Ortaöğretim Öğrencilerinde Görülen Madde Bağımlılı̆̆ Alışkanlığg Ve Yaygınlığı: Bartın İli Örneği

Tablo 1. Öğrencilerin Okul, Sinıf ve Cinsiyetlerine Göre Dă̆ılımı

\begin{tabular}{|c|c|c|c|c|c|c|c|c|c|c|c|c|c|}
\hline \multirow[b]{2}{*}{ Okul } & \multicolumn{3}{|c|}{ 9. siniflar } & \multicolumn{3}{|c|}{ 10. siniflar } & \multicolumn{3}{|c|}{ 11. siniflar } & \multicolumn{3}{|c|}{ 12. siniflar } & \multirow[b]{2}{*}{ GT } \\
\hline & $\mathrm{K}$ & $\mathrm{E}$ & $\mathrm{T}$ & $\mathrm{K}$ & E & $\mathrm{T}$ & $\mathrm{K}$ & $E$ & $\mathrm{~T}$ & $\mathrm{~K}$ & $\mathrm{E}$ & $\mathrm{T}$ & \\
\hline Fen Lisesi & 4 & 4 & 8 & 4 & 4 & 8 & 0 & 0 & 0 & 4 & 4 & 8 & 24 \\
\hline $\begin{array}{c}\text { Anadolu Ögrretmen } \\
\text { Lisesi }\end{array}$ & 0 & 0 & 0 & 0 & 0 & 0 & 4 & 4 & 8 & 0 & 1 & 1 & 9 \\
\hline Anadolu Lisesi & 0 & 0 & 0 & 0 & 0 & 0 & 21 & 19 & 40 & 15 & 7 & 22 & 62 \\
\hline Genel Lise 1 & 15 & 14 & 29 & 17 & 12 & 29 & 0 & 0 & 0 & 0 & 0 & 0 & 58 \\
\hline Genel Lise 2 & 13 & 17 & 30 & 13 & 8 & 21 & 13 & 8 & 21 & 6 & 12 & 18 & 90 \\
\hline $\begin{array}{l}\text { Anadolu İmam } \\
\text { Hatip Lisesi }\end{array}$ & 11 & 22 & 33 & 15 & 16 & 31 & 5 & 13 & 18 & 9 & 15 & 24 & 106 \\
\hline $\begin{array}{l}\text { Endüstri Meslek } \\
\text { Lisesi }\end{array}$ & 0 & 0 & 0 & 0 & 32 & 32 & 0 & 28 & 28 & 0 & 48 & 48 & 108 \\
\hline Kız Meslek Lisesi & 0 & 0 & 0 & 20 & 0 & 20 & 25 & 0 & 25 & 19 & 0 & 19 & 64 \\
\hline $\begin{array}{l}\text { Ticaret Meslek } \\
\text { Lisesi }\end{array}$ & 9 & 15 & 24 & 0 & 0 & 0 & 0 & 0 & 0 & 0 & 0 & 0 & 24 \\
\hline GT & 52 & 72 & 124 & 69 & 72 & 141 & 68 & 72 & 140 & 53 & 87 & 140 & 545 \\
\hline
\end{tabular}

Toplam.

(Bartın İl Milli Eğitim Müdürlüğü, 2010) K: Kız, E: Erkek, T: Toplam, GT. Genel

\subsection{Veri Toplama Araçları}

Araştırmada ortaöğretim öğrencilerinde görülen madde bağımlılığ alışkanlığı ve yaygınlık düzeyini belirlemek için araştırmacılar tarafından geliştirilen anket formu kullanılmıştır. Anket formu iki bölümden oluşmaktadır. Birinci bölümde öğrencilerin sosyo-demografik özellikleri, (cinsiyet, sınıf düzeyi, okul türü) kendilerinden memnuniyet düzeyleri, madde bağımlısı arkadaşlarının olup olmadığına yönelik sorular yer alırken, ikinci bölümde madde kullanımı alışkanlığını saptamaya yönelik sorulara yer verilmiştir.

Araştırma verilerinin toplanması için önce literatür taraması yapılmıştır. İlgili alan yazından yararlanılarak bir anket formu geliştirilmiştir. Geliştirilen ankette öncelikle 72 soru yer almıştır. Taslak anket formu hakkında Eğitimde Psikolojik Hizmetler Bölümünden iki öğretim üyesi, Eğitim Programları ve Öğretimi Bölümünden de iki öğretim üyesinden uzman görüşü alınmıştır. Uzmanların önerileri doğrultusunda, tekrar olan ve gereksiz görülen sorular çıkartılmış ve ayrıca iki soru eklenerek ankete 52 sorudan oluşan son hali verilmiştir. Bu anket formu, her sınıf seviyesinden cinsiyet dağ 1 lımına da dikkat edilerek ortaöğretim öğrencilerine ön deneme amaciyla uygulanmıştır. Ön uygulamada 9,10,11 ve 12. sinifların her birinden 19'ar k1z ve 19'ar erkek olmak üzere toplam 152 öğrenci yer almıştır. Böylelikle soruların anlaşılma derecesi ve öğrencilerin sorulara bakış açısı tespit edilmeye çalışılmıştır. Ön uygulama sonrasında ankete son şekli verilmiştir. 


\subsection{Veri Toplama Yöntemi}

Veri toplama aracı olarak kullanılan anket, sayıları 20 ile 30 kişi arası değişen 24 ayrı öğrenci grubuna, öğrencilere gerekli bilgiler verilerek araştırmacılar tarafindan uygulanmıştır. Gönüllü öğrenciler anketi yanıtlamış ve öğrencilerin isimleri gizli tutulmuştur. Anketlerin doldurulması yaklaşık 40 dakika sürmüştür. Anketler öğrencilerin kendisi tarafından okunarak doldurulmuştur.

\subsection{Veri Analiz Teknikleri}

Verilerin çözümlenmesinde frekans, yüzde ve değişkenler arasındaki farkın anlamlılığını test etmek üzere Pearson ki-kare testi kullanılmıştır (Büyüköztürk, 2002). Değiş̧kenlerin dağılımlarına bakmak için yüzde ve frekans hesaplamaları yapılmıştır. Öğrencilerin cinsiyeti, sınıf düzeyi, devam ettiği okul türü, kendinden memnuniyet düzeyi ve arkadaş grubunda madde bağımlısı olup olmadığ 1 değişkenleri ile madde bağımlılığ bir ilişki olup olmadığını anlamak için ki-kare analizi kullanılmıştır. $\mathrm{Bu}$ çalışmada hata düzeyi 0.05 olarak alınmıştır.

\section{Bulgular ve Tartışma}

Öğrencilerin madde bağımlılı̆̆ı alışkanlığı ve yaygınlığına ilişkin bilgiler Tablo 2'de verilmiştir.

Tabloya göre öğrencilerin \% 38.2'si bir kez bile olsa sigara kullanırken, \% 61.8'i hiç sigara içmemiştir. Öğrencilerin yarısından fazlasının bir kez bile olsa sigara kullanmadığı dikkat çekmektedir. Sigarayı bir kez dahi olsa kullanma oranları ortaöğretim öğrencileriyle ilgili yapılan diğer araştırmalardaki oranlardan oldukça düşüktür. Yaşamlarında en az bir kez sigara içtiklerini belirtenlerin oranı Ögel'in (2000) araştırmasında \% 65.1, ve Yazman'ın (1995) yaptığı araştırmada \%68.0'dır. Öğrencilerin sigara içme sıklığına bakıldığında, bir kez dahi olsa sigara içtiğini belirten 208 öğrencinin \% 28.5'i yalnızca bir kez, \% 29.8'i ise altı ayda 1-2 sigara içmektedir. Sigara içtiğini belirten öğrencilerin yarıdan fazlası da çok fazla içmemektedir. Bunun yanında grubun \% 25.5'i her zaman sigara içtiğini belirtmektedir. Ergenlik döneminde gençler sigara içmeyi, büyüdügünü ve özgür yaşadığını ispatlama aracı olarak görmektedir. Ayrıca sorunlardan uzaklaşmak, heyecan aramak veya meydan okumak gibi nedenlerle de ergenler sigaraya yönelmektedir. Çetin'in 2013 yllında Yalova ilinde gerçekleştirdiği çalışmada, bireylerin 37.2'si sigaraya ilk başladıkları yaşın 11-14 yaşlar, \% 30.9'u 15-18 yaşlar, \% 16.0'sı 7-10 yaşlar arasında ve \% 16.0's1 19 yaş ve üstünde olduğunu belirtmişlerdir. Türkiye Uyuşturucu Raporuna (2012) göre de ülkemiz genelinde, sigaranın \% 75.6'lık oranla ilk başlanılan madde olduğu saptanmıştır. 
Öğrencilerin sigara içmelerinin en önemli nedenleri sırasıyla merak (\%55.7), arkadaş etkisi (\%44.3) ve yalnızlıktır (\%25.5). Akın (1996) tarafindan yapılan araştırmada öğrenciler genellikle özenti, merak, stres, çevreye uyma ve gruba ait olma gibi sebeplerle, sigarayı ilk kez denemişler ve zevk, eğlence, sorunlardan uzaklaşma gibi nedenlerden ötürü sigaray1 kullanmaya devam etmişlerdir. Başka bir araştırmada gençlerin büyük çoğunluğu ilk olarak denedikleri maddenin, kendilerinden yaşça büyük ya da kendi yaşlarında bir arkadaş tarafından verildiğini veya bir grup arkadaş tarafından paylaşıldığını belirtmiştir (Ögel vd, 2004). Taşçı ve arkadaşlarının (2005) çalışmasında da, öğrencilerin sigaraya başlama nedeninin arkadaş etkisi ve özenti olduğu bulunmuştur. Flaherty ve Richman (1993), öğrencilerin en erken kullandıkları bağımlılık yapan maddenin sigara olduğu bulgusuna ulaşmıştır. Öğrencilerin sigaraya başlamada en fazla arkadaşlarından etkilenmesinin nedeni, sigaranın yeni arkadaşlıklarının kurulmasını kolaylaştırması ve sosyal kabul ihtiyacını karşılaması olabilir. Ya da bir gruba dahil olmak isteyen ergen, maddeyi içme ya da kullanma önerisinin reddedilmesi ile arkadaşlarını kaybedeceğini düşünebilir.

\section{İlişkin Bulgular}

Tablo 2. Öğrencilerin Madde Bă̆ımlılı̆̆ı Alışkanlı̆̆ı ve Yaygınlı̆̆ına

\begin{tabular}{|c|c|c|c|c|}
\hline \multicolumn{3}{|c|}{ Zararlı madde } & $\mathrm{n}$ & $\%$ \\
\hline \multirow{24}{*}{ Sigara } & \multirow{3}{*}{$\begin{array}{l}\text { Şimdiye kadar bir kez dahi olsa } \\
\text { sigara kullanma durumu }\end{array}$} & Evet & 208 & 38.2 \\
\hline & & Hayır & 337 & 61.8 \\
\hline & & Toplam & 545 & 100.0 \\
\hline & \multirow[t]{6}{*}{ Sigara içme sıklığ ${ }^{*} *$} & Her zaman & 53 & 25.5 \\
\hline & & Haftada 1-2 tane & 6 & 2.9 \\
\hline & & Ayda 1-2 tane & 28 & 13.5 \\
\hline & & 6 ayda $1-2$ tane & 62 & 29.8 \\
\hline & & Yalnızca bir kez & 59 & 28.5 \\
\hline & & Toplam & 208 & 100.0 \\
\hline & \multirow[t]{6}{*}{ Sigara içme nedeni** } & Merak & 83 & 55.7 \\
\hline & & Arkadaş etkisi & 66 & 44.3 \\
\hline & & Yalnızlık & 38 & 25.5 \\
\hline & & Özenti & 34 & 22.8 \\
\hline & & Aile sorunları & 31 & 20.8 \\
\hline & & Okul sorunları & 24 & 16.1 \\
\hline & \multirow[t]{4}{*}{ Sigarayı temin etme durumu } & Arkadaş & 78 & 43.6 \\
\hline & & Satın alma & 80 & 44.7 \\
\hline & & Ailenin sigarasından & 21 & 11.1 \\
\hline & & Toplam & 179 & 100.0 \\
\hline & \multirow{5}{*}{$\begin{array}{l}\text { Ailesi ve arkadaşlarının sigara } \\
\text { içme durumu** }\end{array}$} & Arkadaş & 101 & 48.5 \\
\hline & & Baba & 44 & 21.1 \\
\hline & & Anne & 29 & 13.9 \\
\hline & & Ağabey & 16 & 7.7 \\
\hline & & Abla & 8 & 3.9 \\
\hline
\end{tabular}


Sosyal Bilimler Dergisi / Cilt: 16, Sayı 1, 2014, 65-84

\begin{tabular}{ccccc}
\hline & & Kardeş & 10 & 4.9 \\
\hline \multirow{2}{*}{ Alkol } & Şimdiye kadar bir kez dahi olsa & Evet & 192 & 35.2 \\
& alkollü içki kullanma durumu & Hayır & 353 & 64.8 \\
& & Toplam & 545 & 100.0 \\
\cline { 2 - 5 } & Alkol kullanma sıklı̆̆1 & Her zaman & 13 & 6.8 \\
& & Haftada 1-2 kez & 6 & 3.1 \\
& & Ayda 1-2 kez & 44 & 23.0 \\
& & 6 ayda 1-2 kez & 70 & 36.1 \\
& & Yalnızca bir kez & 61 & 30.9 \\
Uçucu & Uçucu madde kullanma & Toplam* & 192 & 100 \\
madde & durumu & Evvet & 23 & 4.2 \\
(sıvı, toz & & Hayır & 522 & 95.8 \\
veya gaz) & Uçucu madde kullanma siklığı & Toplam & 545 & 100.0 \\
\cline { 2 - 6 } & & Her gün & 2 & 8.7 \\
& & Haftada en az bir kez & 7 & 30.4 \\
& & Ayda en az bir kez & 1 & 4.3 \\
& & Yalnızca bir kez & 13 & 56.5 \\
& & Toplam & 23 & 100.0 \\
\hline Başlama & Kullanmaya başlanılan dönem & İlköğretim I. kademe & 22 & 12.4 \\
durumu & & Ilköğretim II. kademe & 44 & 24.9 \\
& & Ortaöğretim & 111 & 62.7 \\
& & Toplam & 177 & 100.0 \\
\hline
\end{tabular}

*: Sigara ve alkol kullandığını belirtenler üzerinden yüzde alınmıştır. **: Bu soruda birden fazla seçenek işaretlendiği için toplam alınmamıştır.

Yurt içinde ve yurt dişında yapılan araştırmalarda da arkadaş etkisinin (Berkem ve İpek, 2002; Conrad, Flay ve Hill, 1992; Flay, Hu ve Richardson, 1998; Friedman, Lichtenstein ve Biglan 1985; Kasapila ve Mkandawire, 2010; O'Loughlin vd.,1998; Rose vd., 1999), anne-babadan uzakta ögrrenim görmenin (Kasapila ve Mkandawire, 2010) ve ailede sigara içen birilerinin olmasının (Bauman, Carver ve Gleiter 2001; Bowden, 1990; Chassin, Presson ve Sherman, 1995; Eiser ve Van Der Plight, 1984) sigara alışkanlığında önemli faktörler olduğu ortaya konmuştur.

Öğrencilerin sigarayı nasıl temin ettikleri sorulduğunda, grubun \% 44.7'si satın aldığını, \% 43.6'sı ise arkadaşlarından temin ettiğini belirtmiştir. Görüldüğü gibi öğrencilerin yarıya yakını sigarayı satın almakta ve yine yarıya yakını arkadaşlarından istemektedir. Yine sigara içmede arkadaş etkisi dikkati çekmektedir.

Öğrencilerin ailesinde ya da arkadaşlarında sigara içen olup olmadığ 1 sorulmuş ve buna göre grubun \% 48.5'i arkadaşının, \% 21.1'i babasının, \% 13.9'u annesinin, \% 7.7'si ağabeyinin, \% 3.9'u ablasının ve \% 4.9'u kardeşinin sigara kullandığını belirtmiştir. Yine en fazla yüzdenin arkadaşa ait olduğu görülmektedir. Sigara içen öğrenciler, sigara içenlerle arkadaşlık etmekte, onlardan etkilenerek sigaraya başlamakta ve yine onlardan sigara temin etmektedir. Bu nedenlerle en fazla yüzdenin arkadaşa ait olması şaşırtıcı değildir. Turhan ve arkadaşlarının çalışmasında (2011), babasında ve kardeşinde sigara ve alkol kullanım öyküsü bulunanlarda sigara ve alkol kullanımı olasılığının daha yüksek olduğu saptanmıştır. 
Öğrencilerin alkol kullanma durumu ve sıklığına bakıldığında grubun \% 35.2'si (n=192) şimdiye kadar bir kez bile olsa alkol aldığını, bunların da \% 6.8'i her zaman, \% 23.0'ü ayda bir- iki kez, \% 36.1'i altı ayda bir- iki kez kullandığını söylemiştir. Grubun \% 30.9'u ise yalnızca bir kez alkol almıştır. Ögel (2000) ve arkadaşlarının yaptığı araştırmada son bir ay içinde en az bir kez alkol kullananların oranı \%18'dir. Türkiye'de sekiz üniversitenin birinci sınıf öğrencilerinde yapılan araştırmada öğrencilerin \%22.9'u alkol aldığını söylemiştir (Bertan vd., 2005). Bu araştırmada ayda en az bir kez alkol alanların oranı (\% 23.0) biraz fazla olmakla birlikte yüzdelerin birbirine yakın olduğu söylenebilir.

Öğrencilerin katı, sıv1 ya da gaz uçucu madde kullanma sıklıkları incelendiğinde, \% 4.2'nin $(\mathrm{n}=23)$ uçucu madde kullandığı, bunların \% 17.4'ünün yalnızca denediği ancak \% 8.7'sinin (n=2) her zaman kullandığ görülmektedir. Öğrencilerin \% 89.9'unun uçucu madde (sıvı, toz, gaz) kullanmaması istenilen bir durumdur. Ancak \% 4.2'lik gruptaki öğrencilerin bu tür zararlı maddelere yöneldiği de dikkatten kaçmamalıdır. Ögel'in İstanbul'da lise öğrencileri arasında sigara, alkol ve madde kullanım yaygınlığı konulu araştırmasında, yaşam boyu en az bir kez uçucu madde kullanma oranı \%8.6 olarak bulunmuştur. Son bir yıl içinde en az bir kez uçucu madde kullanma oranı \%4.1, son bir ay içinde ise \%2.8'dir (Ögel, 2000). Bu çalışmada oranların düşük olması sevindirici olmakla birlikte, yine de bu tür zararlı maddeleri kullanan öğrencilerin olması düşündürücüdür.

Öğrencilerin zararlı madde kullanmaya başlama dönemleri \% 12.4 ilköğretim I. kademe, \% 24.9 ilköğretim II. kademe ve \% 62.7 ortaöğretim dönemidir. Görüldüğü gibi, öğrencilerin yarısından fazlası, zararlı madde kullanımına ortaöğretim döneminde başlamıştır. Bu durum madde kullanımı ile ilgili ortaöğretim dönemindeki önleyici ve eğitici çalışmaların gerekliliğini daha da artırmaktadır. Daha önce de belirtildiği gibi, Meclis Araştırma Komisyonu Raporu'na göre (2008), madde kullananların yaklaşık $\%$ 75'i, madde kullanmaya 20 yaşından önce başlamıştır.

Tablo 3'de öğrencilerin sigara ve alkol kullanma durumlarının cinsiyet, sınıf düzeyi, okul türü, kendinden memnun olma ve madde bağımlısı arkadaşı olmasına göre farklılaşıp farklılaşmadığı karşılaştırılmıştır.

Tablo 3. Madde Bağımlılı̆̆ Alışkanlı̆̆ının Bazı Değişkenlere Göre Karşılaş̧tırılması

\begin{tabular}{|c|c|c|c|c|c|c|c|c|c|c|c|c|c|}
\hline \multirow[t]{2}{*}{ Değişken } & \multicolumn{7}{|c|}{ Sigara kullanma durumu } & \multicolumn{6}{|c|}{ Alkol kullanma durumu } \\
\hline & & \multicolumn{3}{|c|}{ Evet } & \multicolumn{2}{|c|}{ Hayır } & $\mathrm{p}$ & & \multicolumn{2}{|c|}{ Evet $*$} & \multicolumn{2}{|c|}{ Hayır } & \\
\hline Cinsiyet & $\mathrm{K}_{1 \mathrm{Z}}$ & 40 & 16.5 & 203 & 82.5 & 23.090 & $.001^{* * *}$ & 25 & 11.6 & 191 & 88.4 & & \\
\hline
\end{tabular}




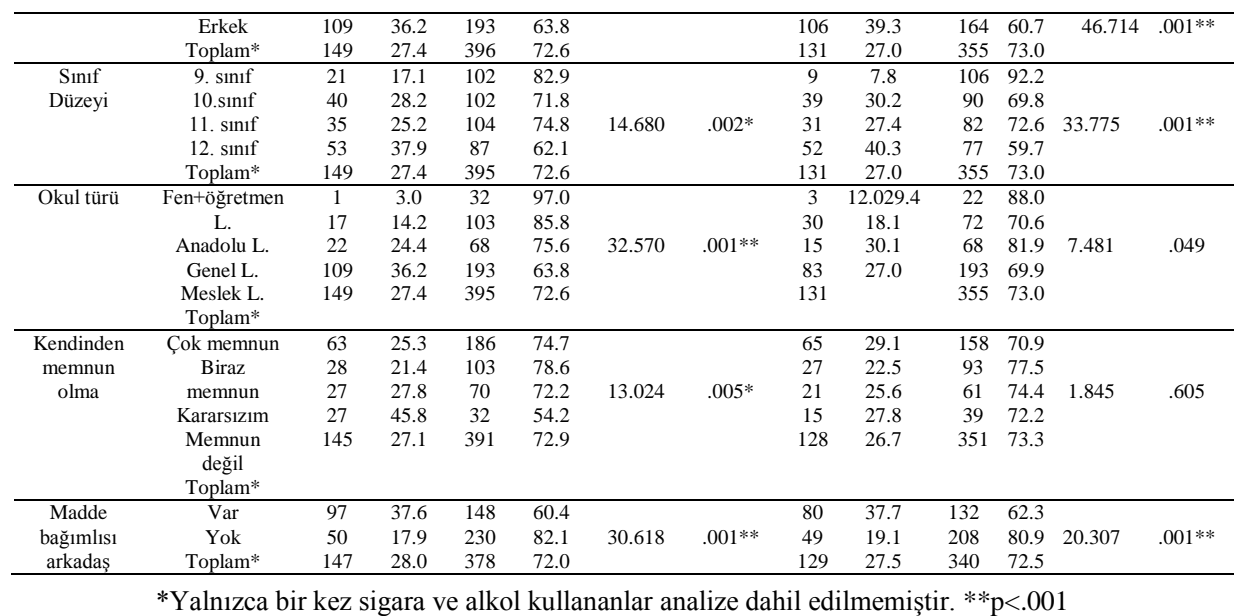

Öğrencilerin sigara içme durumlarının cinsiyetlerine göre değişip değişmediğine ilişkin ki-kare testi sonuçları incelendiğinde, sigara içenlerin oranı kızlarda \%16.5, erkeklerde \% 36.2' dir. Sigara içmeyenlerin oranının ise kızlarda \% 85.5, erkeklerde \% 63.8 olduğu görülmektedir. Öğrencilerin cinsiyeti ile sigara içme durumları arasında .001 düzeyinde anlamlı bir fark vardır $\left(\mathrm{x}^{2}=23.090, \mathrm{p}=0.001\right)$. Buna göre erkek öğrencilerin sigara içme oranının kız öğrencilerden daha fazla olduğu anlaşılmaktadır. Saraçlı'nın (2007), Gökgöz ve Koçoğlu'nun (2007), Web ve arkadaşlarının (1998), Turhan ve arkadaşlarının (2011), Bülbül ve arkadaşlarının (2013) gerçekleştirdiği çalışmalarda da erkek öğrencilerin sigara içme oranı kız öğrencilerden daha fazladır.

Alkol kullananların oranı kızlarda \%11.6, erkeklerde \% 39.3'dür. Alkol kullanmayanların oranının ise kızlarda \% 88.4, erkeklerde \%60.7 olduğu görülmektedir. Cinsiyet ile alkol kullanma durumu arasında anlamlı bir fark olduğu belirlenmiştir $\left(\mathrm{x}^{2}=46.714, \mathrm{p}<.001\right)$. Buna göre erkek öğrenciler sigara kullanmada olduğu gibi, kızlardan daha fazla alkol kullanmaktadır. Başka araştırmalarda da bu çalışma sonuçlarına paralel olarak erkek öğrencilerin kız öğrencilere göre daha fazla alkol tükettiğgi saptanmıştır (Paulson, Coombs ve Richardson, 1990; Sutherland ve Shepherd, 2001).

Tablo 3'de de görüldügü gibi sigara içme oranları sınıf düzeylerine göre farklılaşmaktadır. 9. sınıf öğrencilerinin sigara içme oranı diğer gruplara göre en düşüktür. En fazla sigara içme oranı ise \%37.9'luk oranla 12. yani son sınıflardadır. Analiz sonuçlarına göre öğrencilerin sınıf düzeyi ile sigara içme durumları arasında anlamlı bir fark tespit edilmiştir $\left(\mathrm{x}^{2}=14.680, \mathrm{p}=0.002\right)$. Ülkemizde lise çağındaki öğrenciler üzerinde yapılan bir çalışmada, sigara içme sıklığının \%17.9 - 43.0 arasında değiştiği, sınıf düzeyi arttıkça sigara içme sıklığının da arttığı bulunmuştur (Bilir vd., 1997). Benzer biçimde Taşçı ve arkadaşlarının (2005) bir meslek lisesinde 
gerçekleştirdiği çalışmada da lise son sınıf öğrencilerinin diğerlerine göre daha fazla sigara kullandığı tespit edilmiştir. Amerika'da ortaokul ve lise öğrencileri üzerinde yapılan başka bir çalışmada yaş arttıkça sigara ve alkol kullanımının arttığı saptanmıştır. Beş okuldan 4516 öğrenci ile yapılan bu çalışmada 11 yaşındakilerin \%5.5'i sigara kullanırken bu oran 15 yaşta \% 29.5, 16 yaşta \%29.8'dir (Sutherland ve Shepherd, 2001). Smith (2004) tarafindan gerçekleştirilen bir çalışma sonucuna göre, lise öğrencileri ortaokul öğrencilerine göre bağımlılık yapıcı maddeleri daha fazla kullanmaktadır.

Öğrencilerin sınıf düzeyine göre alkol kullanma oranlarına bakıldığında, 9. sınıf öğrencilerinin \% 7.8'i, 10. sınıf öğrencilerinin \% 30.2 'si, 11. sinıf öğrencilerinin \%27.4'ü ve 12. sinıf öğrencilerinin \% 40.3'ü alkol almaktadır. Görüldüğü gibi 9. sınıf öğrencilerinin alkol kullanma oranı diğer gruplara göre en düşük, 12. sınıf öğrencilerinin alkol kullanma oranı diğer gruplara göre en yüksektir. Ki-Kare testi sonucunda öğrencilerin sınıf düzeyine göre alkol kullanma oranları arasında anlamlı bir farklılık olduğu görülmektedir $\left(x^{2}=33.775, p<.001\right)$. Sınıf seviyeleri arttıkça alkol kullanma oranları da artmaktadır.

Öğrencilerin sigara içme durumunun okul türüne göre farklılaşıp farklılaşmadığı araştırılmıştır. Buna göre, sigara içme oranlarının Fen ve Öğretmen Lisesinde \% 3.0, Anadolu Lisesi öğrencilerinde \% 14.2, Genel Lise öğrencilerinde \%24.4 ve Meslek Lisesi öğrencilerinde \% 36.2 olduğu görülmektedir. Görüldüğü gibi Fen ve Öğretmen Lisesi öğrencilerinin sigara içme oranı diğer gruplara göre oldukça düşüktür. En fazla sigara içme oranı ise \%36.2'lik oranla Meslek Liselerindedir. Öğrencilerin okul türlerine göre sigara içme durumları arasında anlamlı bir farklılık olduğu belirlenmiştir $\left(\mathrm{x}^{2}=32.570, \mathrm{p}<.001\right)$. Başka bir deyişle sigara kullanımı devam edilen okul türüne göre değişiklik göstermektedir. Fen ve Öğretmen Lisesi öğrencilerinin alkol kullanma durumu \% 12.0, Anadolu Lisesi öğrencilerinin \% 29.4, Genel Lise öğrencilerinin \%18.1 ve Meslek Lisesi öğrencilerinin \% 30.1 'dir. Öğrencilerin okul türlerine göre alkol kullanma durumları arasında anlamlı bir farklılık bulunmamıştır $\left(x^{2}=7.841, \mathrm{p}>.05\right)$. Ancak yüzdelere bakıldığında, (sigara kullanmada olduğu gibi), Fen ve Öğretmen Lisesi öğrencilerinin alkol kullanma oranı diğer gruplara göre en düşüktür. Meslek Lisesi ögrencileri ile Anadolu Lisesi öğrencilerinin alkol kullanım oranları yakınlık göstermektedir. En fazla alkol kullanma oranı ise (sigara kullanmada olduğu gibi) \%30.1 oranıyla Meslek Liselerindedir. Uygulama üç farklı meslek lisesinde yapılmıştır (Endüstri Meslek, Ticaret Meslek, Kız Meslek). Tablo 1 incelendiğinde Endüstri Meslek Lisesinde hiç kız öğrenci olmaması yani erkek öğrenci sayısının fazla olması sigara ve alkol kullanma düzeyinin yüksek olmasına yol açmış olabilir. Çünkü hatırlanacağı üzere 
erkek öğrencilerin sigara ve alkol kullanma yüzdesi kız öğrencilerden oldukça yüksektir. Ayrıca Meslek liselerinin yapısına bakıldığında, genellikle sosyo-ekonomik düzeyi düşük ailelerin çocuklarını kısa yoldan meslek sahibi olmaları için bu okullara gönderdiği görülmektedir. Meslek liselerindeki öğrenciler ise düşük puanlarla bu okullara geldikleri için kendilerini daha az başarılı olarak algılamaktadır. $\mathrm{Bu}$ olumsuzlukların yanında özellikle Teknik ve Endüstri meslek liselerinde branşları gereği (mobilya dekorasyon, torna-tesviye vb.) yapıştırıcı maddeleri sıklıkla kullanan öğrenciler, bağımlılık yapıcı maddelere daha kolay yönelmiş olabilirler.

Öğrencilerin sigara içme durumunun kendinden memnuniyet düzeyine göre değişip değişmediğine bakıldığında, çok memnun olanların \% 25.3'ünün, biraz memnun olan öğrencilerin \% 21.4'ünün, ne memnunum ne değilim diyen kararsız öğrencilerin \%27.8'inin ve memnun değilim diyen öğrencilerin \% 45.8'inin sigara içtiği görülmektedir. Buna göre, öğrencilerin kendinden memnun olmaları ile sigara içme durumları arasında anlamlı bir fark olduğu saptanmıştır $\left(\mathrm{x}^{2}=13.024, \mathrm{p}<.001\right)$. Kendinden çok memnun olan öğrencilerin dörtte biri kendinden memnun olmayan öğrencilerin ise yariya yakını sigara içmektedir. En fazla sigara içme oranı kendinden memnun olmayan öğrencilerdedir. Başka bir deyişle sigara içme oranı kendinden memnun olmama durumlarına göre artış göstermektedir.

Alkol kullanan ve kendinden çok memnun olan öğrencilerin oran1 \% 29.1, biraz memnun olanların oranı \% 22.5, ne memnunum ne değilim diyen kararsızların oranı \%25.6 ve memnun değilim diyenlerin oranı \% 27.8'dir. Öğrencilerin kendinden memnun olmaları ile alkol kullanma durumları arasında anlamlı bir farklılık olmadığ p>.05). Kendinden çok memnun olan öğrencilerin alkol kullanma oranı ile kendinden memnun olmayan ögrencilerin alkol kullanma oranları birbirine yakındir.

Öğrencilerin bağımlı arkadaşı olması durumlarına göre sigara içme davranışlarının değişip değişmediği incelendiğinde, sigara içenlerin \%37.6'sının, içmeyenlerin \% 17.9'sunun madde bağımlısı arkadaşı vardır. Öğrencilerin bağımlı arkadaşının olması ile sigara içme durumları arasında anlamlı bir farkl1lık olduğu görülmektedir $\left(\mathrm{x}^{2}=.30 .618, \mathrm{p}<.001\right)$. Bağımlı arkadaşı olanların daha fazla sigara içtiği ifade edilebilir. Daha önce de belirtildiği gibi sigara ve alkol kullanımında arkadaş etkisi önemli bir faktördür. Bu sonuç sigara içmeye başlamanın en önemli nedenlerinden birisinin arkadaş etkisi olması bulgusu ile de tutarlıdır. Alkol ya da sigara kullanan ergenler, alkol ve sigara kullanıcısı olan kişileri arkadaş olarak seçmeye daha fazla eğilimlidirler (Steinberg, 2007). Erdem ve arkadaşlarının (2006) 3168, 10. Sunıf öğrencisi ile gerçekleştirdiği çalışmada madde kullanma riskini arttıran arkadaş özellikleri içinde, öğrencinin madde kullanan arkadaşı bulunmasının ön plana çıktığı ve madde kullanan arkadaşı 
olanların, madde kullanma riskinin 6 kat fazla olduğu bulunmuştur. Taş̧̧ı ve arkadaşlarının çalışmasında da (2005), sigara kullanan lise öğrencilerinin \% 47.1'inin arkadaşı da sigara kullanmaktadır.

Alkol kullanan öğrencilerin \%37.7'sinin, alkol kullanmayanların ise \% 19.1'inin madde bağımlısı arkadaşı bulunmaktadır. Analiz sonuçlarına göre öğrencilerin bağımlı arkadaşı olup-olmama durumu ile alkol kullanmaları arasında anlamlı bir fark olduğu saptanmıştır $\left(x^{2}=.20 .307\right.$, $\mathrm{p}<.001)$. Buna göre alkol kullananların madde bağımlısı arkadaşı olma oranı yüksektir. Chassin ve Delucia (1996) tarafindan yapılan bir çalışmada ergenlerin ailelerinin ve arkadaşlarının alkol kullanmalarının, onların alkol almalarını arttırdığı bulunmuştur. Saraçlı'nın çalışmasında da araştırmamızı destekleyen benzer sonuçlara ulaşılmıştır. Araştırmada arkadaşlarının alkol kullanıyor olmasının öğrencinin alkol kullanımına etkisi incelendiğinde "arkadaşlarının hiçbiri alkol kullanmayanlarda" alkol kullanımı en düşük (\%2.9), "arkadaşlarının hepsi alkol kullananlarda" alkol kullanımı en yüksek (\%83.3) oranda bulunmuştur. Alkol kullanan arkadaş sayısı arttıkça öğrencilerde alkol kullanma riskinin anlamlı oranda arttığı saptanmıştır (Saraçlı 2007:79).

\section{Sonuç ve Öneriler}

Araştırma bulgularına göre öğrencilerin \% 38.2'si $(\mathrm{n}=208)$ şimdiye kadar bir kez dahi olsa sigara içmiştir. Bunların da \% 25.5'i $(n=53)$ her zaman sigara içtiğini belirtmektedir. Öğrencilerin \% 35.2'si $(\mathrm{n}=192)$ şimdiye kadar bir kez dahi olsa alkol kullanmış ve bunların da \% 6.8'i $(n=13)$ her zaman alkol aldığını belirtmektedir. Yine öğrencilerin \% 4.2'si (n=23) şimdiye kadar bir kez dahi olsa uçucu madde (sıvı, katı veya gaz halinde) kullanmış ve bunların da \% 8.7'si (n=2) her gün, \% 30.4'ü $(n=7)$ haftada en az bir kez uçucu madde kullanmaya devam etmektedir. Başka bir deyişle bu öğrencilerin madde bağımlısı olduğu belirtilebilir. Bu konuda en geniş çaplı araştırmalardan birisi olan Meclis Araştırma Komisyonunun raporu ile karşılaştırıldığında (sigara \% 15.6, alkol \% 16.5) bu çalışmada alkol ve sigara kullanma oranları daha yüksektir. Ergenler arasında sigara ve alkol kullanımının giderek arttığı görülmektedir. Öğrencilerin dörtte biri sigara ve alkol kullandığına göre ortaöğretim düzeyindeki öğrencilerin, bağımlılık yapıcı maddelerin zararları ile ilgili bilinçlendirilmelerine yönelik eğitim etkinliklerinin artırılmasına çalışılmalıdır. Bu amaçla okullarda öğrencilere yönelik uzman kişilerce belli aralıklarla seminerler düzenlenmelidir.

Öğrenciler sigaraya en fazla merak ve arkadaş etkisi ile başlamaktadır. Bunları sırasıyla yalnızlık, özenti, aile sorunları, okul sorunları ve büyüdüğünü ispatlama izlemektedir. Öğrencilere sigara, alkol ve 
uyuşturucu maddelerin zararları anlatılmalı, bunları bir kez denemenin bile bazen bağımlılığa yol açabileceği vurgulanmalıdır. Sigara içen öğrencilerin yarısının ailesinin (\% $21.1 \mathrm{baba}, \% 13.9$ anne, \% 7.7 ağabey, \% 3.9 abla, \% 4.9 kardeş) sigara kullandığı, yarısının sigara içen arkadaşının (\% 48.5) olduğu görülmektedir. Madde kullanmayı önleme çalışmaları arkadaş grupları kadar aileleri de içermelidir.

Öğrencilerin sigarayı çoğunlukla satın aldıkları ve arkadaşlarından edindikleri anlaşılmaktadır. 18 yaş altı çocuklara sigara satışı yapılması yasak olduğu halde, ortaöğretim öğrencilerinin sigara satın alabilmesi ilginçtir. İlköğretim ve ortaöğretim öğrencilerine sigara satışı yapan yerler tespit edilmeli ve caydırıcı nitelikli ceza tedbirleri uygulanmalıdır.

Öğrencilerin zararlı madde kullanımına en fazla başladıkları dönem, şu an devam etmekte oldukları ortaöğretim düzeyidir (\% 62.7). Ancak grubun \% 12.4'ü zararlı madde kullanmaya 7-11 yaş aralığını kapsayan ilköğretim I. kademe, \% 24.9'u ise 12-14 yaş aralığını kapsayan ilköğretim II. kademede başladığını belirtmiştir. Kısacası öğrencilerin yaklaşık \% 40'ının zararlı madde kullanmaya çok küçük yaşlarda başladıkları anlaşılmaktadır. $\mathrm{Bu}$ durum madde kullanımı ile ilgili ortaöğretim hatta ilköğretim dönemindeki önleyici ve eğitici çalışmaların gerekliliğini daha da artırmaktadır.

Öğrencilerin sigara ve alkol kullanma durumları bazı değişkenlere göre karşılaştırılmıştır. Buna göre sigara ve alkol kullanma ile cinsiyet, sınıf düzeyi ve madde bağımlısı arkadaşı olması arasında; sigara kullanma ile okul türü ve kendinden memnun olma arasında anlamlı fark bulunmuştur. Başka bir deyişle erkek öğrenciler, 12. sınıf öğrencileri ve daha fazla sayıda madde bağımlısı arkadaşı olanlarda sigara ve alkol; meslek lisesi öğrencileri ve kendinden daha az memnun olanlarda sigara kullanımı daha yüksektir. Son sınıf öğrencileri ve erkek öğrencilerin sigara ve alkol kullanma yüzdeleri daha fazladır. Diğer araştırmalar da erkek öğrencilerin (Meclis Araştırma Komisyonu Raporu, 2008; Saraçl1, 2007; Sutherland ve Shepherd, 2001), büyük öğrencilerin (Bilir vd., 1997; Sutherland ve Shepherd, 2001), madde bağımlısı arkadaşı olan öğrencilerin (Erdem vd., 2006; Kasapila ve Mkandawire, 2010; Ögel vd., 2004) madde bağımlılık oranlarının daha yüksek olduğunu göstermektedir.

Kendinden memnun olmayan ve bağımlı arkadaşı olan öğrencilerin sigara ve alkol kullanma oranının kendinden memnun olan ve bağımlı arkadaşı olmayanlara göre daha fazla olduğu saptanmıştır. Bu nedenle ergenlerin kendilerinden memnuniyet düzeyleri artırılmalı, bu amaçla ergenlerin ders dışındaki boş zamanlarını daha verimli değerlendirmeleri için olanaklar sağlanmalıdır. Ayrıca ergenlere arkadaş seçimi, zararlı madde kullanan arkadaşların ergenler üzerindeki etkileri konusunda bilgiler verilmelidir. 
Madde bağımlılığı ile mücadelede tek sorumluluk okullara yüklenmemelidir. Okuldaki tedbirler ve yasal önlemler bir yere kadar etkili olabilir. Bu mücadelede esas görev ailelere düşmektedir. Aileler çocuklarına ilgi, sevgi ve şefkat göstermekten kaçınmamalıdır. Anne ve babalar özellikle ortaöğretim dönemindeki çocuklarının okul başarılarını, arkadaşlık ilişkilerini, yaşadıkları sorunları iyi gözlemlemeli ve herhangi bir problem olduğunu düşündüklerinde rehber öğretmen veya uzman kişilerle bilgi paylaşımında bulunmalıdır.

$\mathrm{Bu}$ konuda çalışma yapmak isteyen araştırmacılara madde bağımlılığı yaygınlı̆̆ı, madde bağımlılığına yol açan risk faktörler (toplumsal, çevresel ve genetik) konularını periyodik olarak araştırmalarının yanında madde kullanımını önleyici çalışmalar yapmaları önerilmektedir. Özellikle ilkokul ve ortaokul dönemlerinde gerçekleştirilecek bilgilendirme seminerleri, öğrencilerin madde kullanmaya başlamalarını engelleyebilir. Arkadaş etkisinin madde kullanmaya başlamada en önemli etkenlerden birisi olduğu düşünüldüğünde, akran eğitimi modellerinin uygulanması çalışmaları yapılabilir. Çünkü çalışmamızda öğrencilerin özellikle arkadaşlarından etkilendiği, bağımlılık yapıcı maddeleri arkadaşlarından temin ettikleri bulunmuştur. Yapılacak önleyici çalışmaların arkadaşlarla ilgili risk etkenlerini de azaltmaya yönelik olması uygun olacaktır. Ayrıca bu çalışmada ailesel faktörler ve genetik yapı üzerinde fazlaca durulmamıştır. Araştırmacılar anne-babanın madde bağımlısı olma durumunun çocukların madde kullanımı üzerindeki etkisini araştırabilir.

\section{Kaynakça}

Akfert, Serpil K, Çakıcı, Ebru. \& Çakıcı, Mehmet. (2009). Üniversite öğrencilerinde sigara-alkol kullanımı ve aile sorunları ile ilişkisi. Anadolu Psikiyatri Dergisi, Cilt 10, ss. 40-47.

Akın, Münevver. (1999). Lise öğrencilerinin, uyuşturucu-uyarıcı madde kullanımının zararlarına ilişkin sağlık eğitim gereksinimleri. İstanbul Üniversitesi Sağlık Bilimleri Enstitüsü. Yayımlanmamış Yüksek Lisans Tezi, İstanbul.

Alikaşifoğlu, Müjgan. \& Ercan, Oya. (2002). Ergenlerde madde kullanımı. Türk Pediatri Arşivi, Cilt 37, ss. 66-73.

Bauman, Karl. E., Carver, Karen \& Gleiter, Karin. (2001). "Trends in parent and friend influence during adolescent: the case of adolescent cigarette smoking”. Addictive Behaviors, Vol. 26, pp. 349-361.

Baykul, Yaşar. (1997). Istatistik Metotlar ve Uygulamalar. Ankara: An1 Yayıncılık, 2. Bask1. 

Yayınlar1.

Bektaş, Habib. (1991). Uyuşturucu Batağı. İstanbul: Milliyet

Berkem, Nuri \& İpek, Meral. (2002). Öğrenciler Arasında Madde Kullanım Yaygınlı̆̆ı ve Özelliklerinin Belirlenmesi Araştırması. Bursa: Bursa İl Sağlık Müdürlüğü Yayınları.

Bertan, M., Özcebe, H., Haznedaroğlu, D., Kırcalığlu, N. \& Bülbül, SH. (2005). The knowledge of adolescent period and the lifestyle of the first year students in universities. 29th UMEMPS Congress Union of Middle Eastern and Mediterranean Pediatric Societies, Hilton Convention Center, September 14-17, ss. 55-56.

Bilir, Nazmi, Doğan, Bahar \& Yıldız, Ali Naci. (1997). Sigara İçme Konusundaki Davranışlar ve Tutumlar. Ankara: Hacettepe Halk Sağlığ1 Vakfı Yayınları.

Büyüköztürk, Şener. (2002). Sosyal Bilimler İçin Veri Analizi El Kitabı. Ankara: PegemA yayıncılık.

Bowden Vicky R., (1990). The Relationship Between Family Functioning and Adolescent Substance Use. University of San Diego, California United States. Unpublished Master Thesis.

Bülbül, Selda H., Güçlü, Mustafa \& Misırlığlu, Emine D. (2013). Kırıkkale İl Merkezi İlköğretim ve Lise Öğrencilerinde Sigara ve Alkol Alışkanlıkları ve etkileyen faktörler. Türkiye Çocuk hastalıkları Dergisi, Cilt 4, ss. 168-172.

Chassin, Laurie, Presson, Clark C. \& Sherman, Steven J. (1995). "Social-psychological Antecedents and Consequences of Adolescent Tobacco Use". (Ed.) Wallander, J. L. \& Siegel, L. J., Adolescent Health Problems: Behavioral Perspectives Advances in Pediatric Psychology, pp. 141-159. New York, NY: Guilford Press.

Conrad, Karen M., Flay, Brian R. \& Hill, David. (1992). "Why Children Start Smoking Cigarettes: Predictors of Onset". British Journal of Addiction, Vol. 87, pp. 1711-1724.

Çetin, Yılmaz. (2013). "Madde Bağımlılı̆̆ı Ve Yalova Ölçeğinde Madde Bağımlılı̆̆ı Algısı." Yayımlanmamış Yüksek Lisans Tezi, Yalova Üniversitesi Sosyal Bilimler Enstitüsü, Yalova.

Doğan, Derya G. \& Ulukol, Betül. (2010). "Ergenlerin Sigara İçmesini Etkileyen Faktörler ve Sigara Karşıtı İki Eğitim Modelinin Etkinliği'”. Inönü Üniversitesi Tıp Fakültesi Dergisi. Cilt, 17, Say1 3, ss. 179185.

E1ser, Jichard R. \& Van Der Pligt, Joop. (1984). "Attitudinal and Social Factors in Adolescent Smoking: In Search of Peer Group Influence". Journal of Applied Social Psychology, Vol. 14, pp. 348-363. 
Erdem, Gizem, Eke, Ceyda Y., Ögel, Kültegin ve Taner, Sevil. (2006). "Lise Öğrencilerinde Arkadaş Özellikleri Ve Madde Kullanımı." Bağımlılık Dergisi, Cilt 7, ss. 111-116.

Flaherty, Joseph A., Richman, Judith A. (1993). "Substance Use and Addiction Among Medical Students, Residents and Physicians". Psycological Clinics of North America, Vol. 16, No. 1, pp. 189197.

Flay, Brian R., Hu, Frank B. \& Richardson, Jean. (1998). "Psychosocial Predictors of Different Stages of Cigarette Smoking Among High School Students". Preventive Medicine, Vol. 27, pp. 9-18.

Friedman, Larry. S., Lichtenstein, Edward \& Biglan, Anthony. (1985). "Smoking Onset Among Teens: An Empirical Analysis of Initial Situations". Addictive Behaviors, Vol. 10, pp. 1-13.

Gökgöz, Şenlen \& Koçoğlu, Gülay. (2007). "Adölesan Çağda Sigara ve Alkol Ölçme Davranışı. Klinik Araştırma”. Fırat Üniversitesi: Firat Tip Dergisi, Cilt 12, Say1 3, ss. 214-218

Gürol, Defne Tamar. (2008). Madde Bă̆ımlılı̆̆ı Açısından Riskli Adolesanlar. İ.Ü. Cerrahpaşa Tıp Fakültesi Sürekli Tıp Eğitimi Etkinlikleri. Adolesan Sağlığı II. Sempozyum Dizisi No. 63, ss. 65-68.

Herken, Hasan, Özkan, İshan, Çilli, Ali S. \& Bodur, Said. (2000). "Öğrencilerde Alkol Kullanım Sıklığı ve Sosyal Öğrenme ile ilişkisi”. Düşünen Adam: Psikiyatri ve Nörolojik Bilimler Dergisi, Cilt 13, ss. 87-91.

Herken, Hasan, Bodur, Said. \& Kara, Fatih. (2000). Üniversite "Öğrencisi Kızlarda Madde Kullanımı İle Kişilik ve Ruhsal Belirti İlişkisi”. Klinik Psikiyatri, Cilt 3, ss. 40-45

Karasar, Niyazi. (2006). Bilimsel Araştırma Yöntemi. Ankara: Nobel Yayın Dağıtım.

Kasapıla, William. \& Mkandawıre, Tapiwa Susan. (2010). "Drinking and Smoking Habits Among College Students in Malawi". European Journal of Social Sciences. Vol. 15, No. 3, pp.441-448.

Köknel, Özcan. (1998). Bă̆ımlılık - Alkol ve Madde Bağımlılı̆̆ı. İstanbul: Altın Kitaplar Yayınevi.

Meclis Araştırma Komisyonu Raporu (2008). Uyuşturucu Başta Olmak Üzere Madde Bağımlılı̆̆ ve Kaçakçılı ̆̆ Sorunlarının Araştırılarak Alınması Gereken Önlemlerin Belirlenmesi Amacryla Kurulan Komisyon. Ankara: TBMM Yayınları.

O'loughlın, Jennifer, Paradıs, Gilles, Renaud, Lise \& Gomez, Luis Sanchez (1998). "One-Year Predictors of Smoking Initiation and of Continued Smoking Among Elementary School Children in Multiethnic, 
Low-İncome, İnner-City Neighbourhoods". Tobacco Control, Vol. 7, pp. 268-275.

Ögel, Kültegin, Tamar, Defne, Evren, Cüneyt. Çakmak, Duran (2000). "İstanbul'da Lise Gençleri Arasında Sigara, Alkol ve Madde Kullanım Yaygınlığı”. Klinik Psikiyatri Dergisi. Cilt 3, Sayı 4, ss. 242-245.

Ögel, Kültegin. (2001). İnsan, Yaşam ve Băğmlılık. Tartışmalar ve Gerekçeler. İstanbul: IQ Kültür Sanat Yayınc1lık.

Ögel, Kültegin, Çorapçığlu, Aytül, Sır, Aytekin, Tamar, Müge, Tot, Şenel, Doğan, Orhan, Uğuz, Şükrü, Yenilmez, Çınar, Bilici, Mustafa, Tamar, Defne \& Liman, Olcay. (2004). "Türkiye'de Dokuz İlde İlk ve Ortaöğretim Öğrencilerinde Tütün, Alkol Ve Madde Kullanım Yaygınlığı”. Türk Psikiyatri Dergisi. Cilt 15, Sayı 2, ss. 112-118.

Ögel, Kültegin, Taner, Sevil, Eke \& Ceyda Y. (2006). "Onuncu Sinıf Öğrencileri Arasında Tütün, Alkol ve Madde Kullanım Yaygınlığı (İstanbul Örneklemi)". Bă̆ımlılık Dergisi. Cilt 7,Sayı 1, ss:18-23.

Ögel, Kültegin, Taner, Sevil. \& Eke, Ceyda Y. (2006). "Onuncu Sınıf Öğrencileri Arasında Tütün, Alkol Ve Madde Kullanım Yaygınlığı: İstanbul Örneklemi”. Bă̆ımlılık Dergisi, Cilt 7, ss. 18-23.

Paavola, M., Vartianien, E. \& Puska, P. (2001). Smoking cesation between teenage years and adulthood. Health Education Research. Vol. 16, No. 1, pp. 49-57.

Paulson, Morris J., Coombs, Robert H. \& Richardson, Mark A. (1990) "School Performance, Academic Aspirations, and Drug Use Among Children and Adolescents". Journal of Drug Education, Vol. 20, No. 4, pp. 289-303.

Rezvanfard, M., Ekht1arı, H. \& Mokrı A. (2009). Psychological and behavioral traits in smokers and their relationship with nicotine dependence level. Archives of Iranian Medicine. Vol. 13, pp. 395-405.

Rose, Jennifer S., Chassin, Laurie, Presson, Clark. \& Sherman, Steven J. (1999). "Peer Influences on Adolescent Cigarette Smoking: A Prospective Sibling Analysis". Merrill-Palmer Quarterly, Vol. 45, pp. 6284.

Saraçl1, Özge. (2007). Zonguldak Karaelmas Üniversitesi Ögrrencilerinde Sigara, Alkol veMadde Kullanımı İle İlişkili Bireysel ve Psikososyal Faktörler. Zonguldak Karaelmas Üniversitesi Tıp Fakültesi. Yayımlanmamış Yüksek Lisans Tezi, Zonguldak.

Smith, Donna Carroll. (2004). Substance Use Attitudes and Behaviors of Students With Learning Disabilities. The Ohio State University, Unpublished Doctoral Thesis, Ohio. 
Springer, J.F., Sale, E. \& Hermann, J. (2004). Characteristics of effective substance abuse prevention programs for highrisk youth. The Journal of Primary Prevention. Vol. 25, pp. 171-219.

Steinberg, Laurence. (2007). Ergenlik. (Çev.Ed. Figen Çok). İstanbul: İmge Kitabevi.

Sutherland, I. \& Shepherd, J.P. (2001). "Social Dimensions of Adolescent Substance Use”. Addiction. Vol. 96, pp. 445-458.

Tekalan, Ali (2012). "Uyuşturucu Maddelere Genel Bir Bakış" Yeşilay, Bağımlılık Tedavisi, Aylık sağlık, Eğitim ve Kültür Dergisi,Yı1: 87, Say1 936, Ocak, s.32.

Taşçı Emel, Atan, Şenay Ü., Durmaz, Nazike, Erkuş, Hilal \& Sevil, Ümran. (2005). Kız Meslek Lisesi Öğrencilerinin Madde Kullanma Durumları. Bağımlılık Dergisi, Cilt 6, ss. 122-128.

Turhan, Ebru, İnand1, Tacettin, Özer, Cahit. \& Akoğlu, Sabahat (2011). "Üniversite öğrencilerinde madde kullanımı, şiddet ve bazı psikolojik özellikler”. Türkiye Halk Sağlı̆̆ Dergisi. Cilt 9, No.1, ss. 33-44.

Türkiye'nin Uyuşturucu ile Mücadele Politikası (2012). utsamwww.utsam.org.tr Erişim Tarihi: 04.03.2014.

Vadım, Yuferov, Levran, Orna, Proudnıkov, Dmitri. (2010). "Search for genetic markers and functional variants ivolved in the development of opiate and cocaine addiction and treatment." Annals of the New York Academy of Sciences. Vol. 1187, pp. 184-207.

Yazman, Ümit. (1995). Lise Gençliğinin Psikoaktif Maddelere Bakışı ve Kullanım Oranlarının Türkiye- İstanbul Örneği ile İncelenmesi. Bakırköy Ruh ve Sinir Hastalıkları Hastanesi. Yayınlanmamış Uzmanlık Tezi, İstanbul.

Yörükoğlu, Atalay. (1996). Gençlik Çă̆g. İstanbul: Özgür Yayınları.

Webb, E., Ashton, G.H., Kely, P., Kamal1, F. (1998). "An Update on British Medical Students' Lifestyles”. Medical Education. Vol. 32, No.3, pp. 325-331.

Zincir, Selma B., Zincir, Nihat, Sünbül, Esra A. \& Kaymak, Esra (2012). "Sigara Bağımlılığında Mizaç ve Karakter Özelliklerinin Bağımlılık Düzeyleri ile İlişkisi”. Journal of Mood Disorders, Cilt. 2, Sayı 4, ss. 160166. 